\title{
PERANAN REAKSI STRES KERJA TERHADAP KUALITAS HIDUP PADA PEKERJA LEVEL OPERATOR
}

\author{
Kresna Surya Wijaya ${ }^{1}$, Rismiyati Koesma ${ }^{2}$ Zamralita $^{3}$ \\ ${ }^{1}$ Fakultas Psikologi Profesi Klinis, Universitas Tarumanagara Jakarta \\ Email: kresnasw@gmail.com \\ ${ }^{2}$ Fakultas Psikologi, Universitas Tarumanagara Jakarta \\ Email: ristetty@gmail.com \\ ${ }^{3}$ Fakultas Psikologi, Universitas Tarumanagara Jakarta \\ Email: zamralita04@yahoo.com
}

Masuk :06-04-2019, revisi: 09-09-2019, diterima untuk diterbitkan :09-09-2019

\begin{abstract}
ABSTRAK
Stres kerja merupakan permasalahan global yang banyak dialami oleh karyawan, selain berdampak kepada organisasi stres kerja juga dapat berdampak kepada kualitas hidup karyawan. Kualitas hidup merupakan aspek penting dalam hidup karyawan, diketahui bahwa karyawan dengan kualitas hidup yang baik akan cenderung lebih produktif. Secara personal, karyawan dengan kualitas hidup yang baik cenderung memiliki kesehatan mental yang baik. Penelitian ini bertujuan untuk melihat pengaruh dari reaksi stres kerja terhadap kualitas hidup pada karyawan. Penelitian dilakukan terhadap 227 karyawan level operator di PT.X yang berlokasi di Tangerang. Analisis statistik dilakukan menggunakan uji regresi linear dengan bantuan program SPSS versi 23. Hasil penelitian menunjukan bahwa stres kerja memiliki pengaruh terhadap kualitas hidup dengan nilai beta negatif $(F=452.885, \mathrm{p}<0.05)$. Dimensi reaksi stres kerja, seperti reaksi fisik stres kerja $(b=-420, p<0.05)$, reaksi psikologis stres kerja $(b=-408, p<0.05)$ dan reaksi prilaku stres kerja $(b=-140, p<0.05)$ memiliki pengaruh signifikan dengan kualitas hidup karyawan dengan nilai beta negatif. Berdasarkan hasil tersebut peneliti menyarankan terapi brief mindfulness sebagai cara yang dapat dilakukan untuk mengurangi stres kerja.
\end{abstract}

Kata Kunci: Stres Kerja, Kualitas Hidup, Pekerja Pabrik

\section{ABSTRACT}

Job stress is a global issue commonly experienced by employees, affecting their quality of life in addition to the organization. Being an important aspect in employees' lives, those with good quality of life tend to be more productive and mentally healthy. This study aims to look at the effect of work stress reactions on quality of life of employees. The study was conducted on 227 operator level employees at PT. X, located in Tangerang. Statistical analysis was performed using linear regression test with the help of SPSS version 23. The result shows that work stress affects quality of life with negative beta value $(F=452,885, p<0.05)$. Dimensions of work stress reactions, such as work stress physical reaction $(b=-420, p<0.05)$, work stress psychological reaction $(b=-408, p<0.05)$ and work stress behavioral reaction $(b=-140, p<0.05)$ have significant influence on the quality of life of employees with negative beta scores. Based on these results researchers suggest brief mindfulness therapy as a mean to reduce work stress.

Keywords: work stress, life quality, factory workers

\section{PENDAHULUAN}

\section{Latar Belakang}

Globalisasi ekonomi yang terjadi memiliki dampak postif dan juga tantangan tersendiri bagi negara berkembang. Secara teori, globalisasi bertujuan untuk membantu negera-negara berkembang dalam memperisapkan lapangan pekerjaan baru. Ketersediaan lapangan pekerjaan baru tersebut akan menambah pendapatan negara yang kemudian dapat digunakan untuk mengembangkan fasilitas-fasilitas kesehatan, sosial, pelatihan, pendidikan, penelitian dan berbagai hal lainnya. Disamping dampak positif, pekerja di negara berkembang juga akan dihadapkan kepada tantangan baru yang berkaitan dengan perubahan-perubahan dari model pekerjaan. Pekerja di negara-negara berkembang akan dihadapkan dengan berbagai tantangan baru 
seperti, meningkatnya tuntutan untuk mempelajari kemampuan baru, mengadopsi cara kerja baru, tekanan untuk produktivitas yang lebih tinggi, persaingan kerja, tekanan waktu dan tuntutan akan kualitas kerja yang tinggi. Pekerja yang gagal dalam memenuhi tuntutan-tuntutan tersebut sering kali mengalami stres kerja (WHO, 2007).

Stres kerja merupakan sebuah fenomena global yang saat ini sedang dihadapi baik oleh para pekerja maupun pemberi kerja di negara maju maupun negara berkembang. Hasil survei yang dilakukan dari berbagai negara di Eropa, Amerika Serikat dan Australia menemukan bahwa sekitar 2/3 dari pekerja pernah mengalami stres kerja. Pada survei yang dilakukan di Jepang menunjukan bahwa lebih dari 32\% pekerja mengalami kecemasan dan stres berat akibat dari kondisi kerjanya, sedangkan di Korea, 20\% pekerja melaporkan adanya tekanan kerja dan beban kerja yang berat di tempat kerja (ILO, 2016).

Hasil survei yang dilakukan oleh Perinelli dan Beker (2011) juga menunjukan bahwa stres kerja merupakan fenomena yang terjadi di Indonesia. Survei kepada 1500 pekerja di Indonesia menunjukan bahwa $80.39 \%$ responden merasa bahwa pekerjaannya saat ini membuat dirinya merasa stres, $78.84 \%$ responden mengatakan bahwa pekerjaan yang dilakukannya membuat dirinya merasa kelelahan secara fisik dan $73.12 \%$ responden mengatakan bahwa pekerjaanya yang dilakukannya membuat dirinya lelah secara mental. WHO (2007) mendefinisikan stres kerja sebagai sebuah pola reaksi fisiologis, psikologis, kognitif dan perilaku terhadap beberapa aspek dari pekerjaan, organisasi kerja dan lingkungan kerja. Ketika individu mengalami stres kerja, maka mereka akan merasa tertekan dan merasa tidak bisa mengatasi masalah yang sedang dihadapi. Individu dikatakan mengalami stres kerja, ketika dirinya merasakan adanya reaksi fisik dan psikologis yang mengganggu, sebagai akibat dari ketidaksesuaian tugas kerja dengan kemampuan nyata dari pekerja. Hal ini sejalan dengan teori stres kerja oleh Palmer, Copper dan Thomas (2004), diketahui terdapat tiga reaksi stres kerja yang akan dirasakan oleh individu. Pertama adalah reaksi fisik seperti, darah tinggi, sakit kepala, sakit punggung dan masalah pencernaan. Kedua, rekasi secara psikologi, seperti mudah tersinggung dan munculnya perasaan-perasaan negatif. Terakhir adalah reaksi perilaku, seperti gangguan tidur, ketergantungan akan kopi, merokok dan minumminuman beralkohol secara berlebihan.

Hasil penelitian terdahulu menunjukan bahwa terdapat hubungan antara stres kerja dengan kualitas hidup. Beberapa hasil penelitian menunjukan adanya dampak negatif dari stres kerja terhadap kualitas hidup pada pekerja. Seperti yang diungkapkan oleh Sarafis, Rousaki, Tsounis, Malliarou, Lahana, dan Bamidis, (2016) dalam penelitiannya terhadap 246 pekerja medis. Hasil penelitiannya menunjukan bahwa stres kerja memiliki dampak negatif pada kualitas hidup. Penurunan pada kualitas hidup ini juga berkorelasi positif dengan penurunan tingkat kualitas pelayanan pada para pekerja medis. Hasil penelitian yang dilakukan oleh Sio et al. (2017) juga mendukung bahwa stres kerja memiliki dampak yang negatif pada kualitas hidup, terutama pada pekerja perempuan. Penelitian yang dilakukan oleh Choi, Jang, Lee, Park dan Han (2018) juga menunjukan hasil yang sama, di mana hasil penelitiannya menunjukan bahwa terdapat penurunan kualitas hidup ketika stres kerja meningkat. Hasil berbeda ditunjukan oleh penelitian yang dilakukan Babu et al. (2016) kepada pekerja IT di India. Hasil penelitiannya menunjukan bahwa stres kerja berkorelasi secara positif terhadap kualitas hidup. Menurut Babu et al, stres kerja dapat menjadi suatu bentuk motivasi yang dapat meningkatkan kualitas hidup pekerja.

Kualitas hidup sendiri didefinisikan sebagai persepsi individu dari posisi individu dalam hidup dalam konteks sistem budaya dan nilai dimana individu hidup dan dalam kaitannya dengan tujuan, harapan, standar dan kekhawatiran (WHOQOL-Group, 1998). Saat ini, kualitas hidup pekerja 
merupakan aspek penting yang banyak menjadi perhatian dari para pemimpin perusahaan. Hasil survei yang dilakukan oleh Sodexo (2015) mengatakan bahwa sebagian besar pemimpin perusahaan memandang kualitas hidup pekerja merupakan aspek penting dalam meningkatkan performa kerja pekerja. Hal ini juga di dukung oleh hasil peneltian yang dilakukan Susniene dan Jurkauskas (2009) di mana kualitas hidup memiliki hubungan postif dengan kualitas dari hasil kerja.

Berdasarkan latar belakang yang telah dipaparkan di atas, diketahui bahwa terdapat perbedaan pendapat terkait hubungan stres kerja dengan kualitas hidup pekerja. Lebih lanjut, terbatasnya penelitian yang membahas terkait pengaruh dari stres kerja pada kualitas hidup pekerja level operator di Indonesia membuat peneliti tertarik untuk melakukan penelitian pengaruh dari stres kerja terhadap kualitas hidup pada pekerja level operator di PT.X.

\section{Rumusan Masalah}

Berdasarkan latar belakang masalah yang telah dipaparkan, maka rumusan masalah dalam penelitian ini adalah "Apakah reaksi stres kerja memiliki peran terhadap kualitas hidup dari pekerja level operator di PT. X?”.

\section{METODE PENELITIAN}

Subjek dalam penelitian ini memiliki karakteristik sebagai berikut: (a) karyawan tetap PT. X, (b) bekerja sebagai operator cutting. Dalam penelitian ini, populasi penelitian adalah seluruh pekerja level operator pada divisi cutting di PT. X sebanyak 420 pekerja. Sampel pada penelitian ini adalah 227 pekerja. Berdasarkan data demografis diketahui bahwa mayoritas subjek pada penelitian ini berjenis kelamin perempuan (77.1\%), berusia antara 25-35 tahun (41.9), memiliki masa kerja selama 5-10 tahun (48\%), dan berstatus menikah (90.3\%). Secara lebih jelas, data demografi subjek dapat dilihat pada table 4.1

Tabel 1 Demografi Subjek

\begin{tabular}{|c|c|c|c|c|}
\hline & Keterangan & Mean/SD & $\mathbf{N}$ & Persen (\%) \\
\hline \multirow[t]{2}{*}{ Jenis Kelamin } & Laki-laki & & 52 & $22.9 \%$ \\
\hline & Perempuan & & 175 & $77.1 \%$ \\
\hline \multirow[t]{5}{*}{ Usia } & & $34.5 / 7.7$ & & \\
\hline & 17 tahun -25 tahun & & 28 & $12.3 \%$ \\
\hline & $>25$ tahun -35 tahun & & 95 & $41.9 \%$ \\
\hline & $>35$ tahun -45 tahun & & 82 & $36.1 \%$ \\
\hline & $>45$ tahun -55 tahun & & 22 & $9.7 \%$ \\
\hline \multirow[t]{7}{*}{ Masa Kerja } & & $9.85 / 5.59$ & & \\
\hline & $<1$ tahun -5 tahun & & 39 & $17.2 \%$ \\
\hline & $>5$ tahun -10 tahun & & 109 & $48 \%$ \\
\hline & $>10$ tahun -15 tahun & & 43 & $18.9 \%$ \\
\hline & $>15$ tahun -20 tahun & & 22 & $9.7 \%$ \\
\hline & $>20$ tahun -25 tahun & & 11 & $4.8 \%$ \\
\hline & $>25$ tahun & & 3 & $1.3 \%$ \\
\hline \multirow[t]{3}{*}{ Status Pernikahan } & Menikah & & 205 & $90.3 \%$ \\
\hline & Belum Menikah & & 17 & $7.5 \%$ \\
\hline & Bercerai & & 5 & $2.2 \%$ \\
\hline
\end{tabular}


Peneltian dilakukan menggunakan pendekatan kuantitatif. Pendekatan ini didefinisikan oleh Aliaga dan Gunderson (2002) sebagai suatu cara untuk menjelaskan fenomena dengan mengumpulkan data numerik yang kemudian di analisis menggunakan metode berbasis matematis (khususnya statistik). Pada penelitian ini beberapa desain dari pendekatan kuantitatif akan digunakan untuk menjawab pertanyaan penelitian.

\section{Instrument Penelitian}

Variabel kualitas hidup diukur menggunakan alat ukur WHOQOL-BREF yang dikembangkan oleh World Health Organization. Adaptasi kedalam bahasa Indoneisa dilakukan oleh Fakultas Psikologi Universitas Tarumanagara, Jakarta. Kuesioner WHOQOL-BREF mengukur empat dimensi dalam kualitas hidup. Empat dimensi yang diukur dalam WHOQOL-BREF adalah: Dimensi fisik mengacu pada aspek kesehatan organik, mengumpulkan informasi terkait tentang rasa sakit, ketidaknyamanan, energi kelelahan, mobilitas, dan kebutuhan untuk perawatan medis. Dimensi psikologis berhubungan dengan pengaruh positif, ingatan, konsentrasi, harga diri, citra tubuh dan penampilan. Dimensi hubungan sosial yang menyelidiki hubungan interpersonal dan jaringan dukungan sosial. Dimensi lingkungan berisi pertanyaan yang berkaitan dengan keselamatan fisik dan perlindungan, sumber daya keuangan, transportasi, dan kondisi tempat tinggal. Jumlah seluruh butir dari alat ukur ini adalah 26 butir, yang terdiri dari 23 butir positif dan 3 butir negatif. Alat ukur menggunakan skala likert yang terdiri dari lima pilihan jawaban, yaitu seperti sangat buruk (1), buruk (2), biasa-biasa saja (3), baik (4), dan sangat baik (5).

\section{Tabel.2 Blueprint Alat Ukur Kualitas Hidup}

\begin{tabular}{|c|c|c|c|}
\hline Domain & Butir & Contoh Butir & Interpretasi \\
\hline Fisik & $3,4,10,15,16,17,18$ & $\begin{array}{l}\text { Saya memiiki cukup tenaga } \\
\text { untuk melakukan kegiatan } \\
\text { sehari-hari }\end{array}$ & $\begin{array}{l}\text { Semakin tinggi skor pada dimensi } \\
\text { fisik, mengindikasikan semakin } \\
\text { tinggi kepuasan individu akan } \\
\text { kondisi fisiknya }\end{array}$ \\
\hline Psikologis & $5,6,7,11,19,26$ & $\begin{array}{l}\text { Seberapa puas Anda menikmati } \\
\text { hidup Anda? }\end{array}$ & $\begin{array}{l}\text { Semakin tinggi skor pada dimensi } \\
\text { fisik, mengindikasikan semakin } \\
\text { tinggi kepuasan individu akan } \\
\text { kondisi psikologisnya }\end{array}$ \\
\hline Hubungan & $20,21,22$ & $\begin{array}{l}\text { Seberapa puas anda dengan } \\
\text { dukungan yang Anda dapatkan } \\
\text { dari teman-teman Anda? }\end{array}$ & $\begin{array}{l}\text { Semakin tinggi skor pada dimensi } \\
\text { fisik, mengindikasikan semakin } \\
\text { tinggi kepuasan individu akan } \\
\text { hubungan sosialnya }\end{array}$ \\
\hline Lingkungan & $8,9,12,13,14,23,24,25$ & $\begin{array}{l}\text { Seberapa sehat lingkungan fisik } \\
\text { di sekitar Anda? }\end{array}$ & $\begin{array}{l}\text { Semakin tinggi skor pada dimensi } \\
\text { fisik, mengindikasikan semakin } \\
\text { tinggi kepuasan individu akan } \\
\text { kondisi lingkungan fisiknya }\end{array}$ \\
\hline
\end{tabular}

Untuk mengukur dan mendapatkan gambaran stres kerja, dalam penelitian ini, peneliti menggunakan dua instrumen berbeda. Instrumen pertama adalah, alat ukur skala stres yang dikembangkan oleh Fakultas Psikologi Universitas Tarumanagara. Sebelum digunakan dilakukan modifikasi alat ukur sesuai dengan kebutuhan penelitian. Instrumen ini mengukur tiga dimensi dari reaksi stres. Pertama, dimensi fisik yang terkait dengan perubahan fisik yang dirasakan individu sebagai akibat dari stres. Semakin tinggi nilai pada dimensi fisik, mengindikasikan semakin banyak reaksi stres fisik yang dirasakan Kedua, dimensi psikologis yang terkait dengan perubahan kondisi psikologis individu sebagai akibat dari stres. Semakin tinggi skor pada dimensi psikologis, mengindikasikan semakin tinggi reaksi stres psikologis yang dirasakan. Terakhir, adalah dimensi perilaku, yang terkait dengan perubahan perilaku yang dialami individu sebagai akibat dari stres. Semakin tinggi skor pada dimensi perilaku mengindikasikan semakin banyak gangguan perilaku yang dirasakan akibat dari stres kerja. 
Tabel 3. Blueprint Alat Ukur Reaksi Stres Kerja

\begin{tabular}{cccc}
\hline No & Dimensi & Butir & Jumlah \\
\hline $\mathbf{1}$ & Fisik & $1,2,3,4,5,6,7,8,9,10,11,12,13,14,15,16,17,18,19,20,21,22,23$ & 23 \\
$\mathbf{2}$ & Psikologis & $24,25,26,27,28,29,30,31,32,33,34,35,36,37,38,39,40,41,42,43,44$ & 21 \\
$\mathbf{3}$ & Perilaku & $45,46,47,48,49,50,51,52,53,54,55,56,57,58,59,60,61,62$ & 18 \\
\hline
\end{tabular}

Pada penelitian ini, uji reliabilitas internal menunjukan bahwa Skala Stres merupakan alat ukur yang reliabel. Nilai cronbach alpha pada setiap dimensi berkisar antara .78 - .87. dengan nilai Corrected Item-Total Correlation pada setiap butir lebih dari .200. Validitas dilakukan dengan cara melakukan face validity dan content validity. Face validity dilakukan kepada 30 sampel try out sebelum alat ukur digunakan. Content validity didasarkan kepada persetujuan expert. Dalam penelitian ini content validity dilakukan oleh kedua dosen pembimbing dan satu dosen yang ahli di bidang psikologi industri dan organisasi. Hasil uji validitas menunjukan bahwa tidak ada perubahan dari butir alat ukur yang digunakan.

Instrumen kedua yang digunakan untuk melihat gambaran stres kerja adalah kuesioner HSE Management Standart Indicator tools. HSE Management Standart Indicator tools merupakan kuesioner yang digunakan untuk mengukur faktor resiko stres kerja. Kuesioner ini dikembangkan oleh tim HSE berdasarkan model teori stres kerja dari Palmer, Copper \& Thomas (2003). Kuesioner ini menggunakan lima skala likert yaitu, tidak pernah (1), jarang (2), kadang-kadang (3), sering (4), sangat sering (5). HSE Management Standart Indicator tools yang digunakan dalam penelitian ini merupakan versi bahasa indonesia yang pernah digunakan pada beberapa penelitian sebelumnya (Erdius \& Dewi, 2017, Fahmansyah, 2017).

Tabel 4 Blueprint Alat Ukur Sumber Stres Kerja

\begin{tabular}{cllc}
\hline No & \multicolumn{1}{c}{ Dimensi } & \multicolumn{1}{c}{ Butir } & Jumlah \\
\hline $\mathbf{1}$ & Demand (+) & $1,2,3,4,5,6,7,8$ & 8 \\
$\mathbf{2}$ & Control (-) & $9,10,11,12,13,14$ & 6 \\
$\mathbf{3}$ & Managerial Support (-) & $15,16,17,18,19$ & 5 \\
$\mathbf{4}$ & Peer Support (-) & $20,21,22,23$ & 4 \\
$\mathbf{5}$ & Relationships (-) & $24,25,26,27$ & 4 \\
$\mathbf{6}$ & Role (+) & $28,29,30,31,32$ & 5 \\
$\mathbf{7}$ & Change (+) & $33,34,35$ & 3 \\
\hline
\end{tabular}

Pada penelitian ini, uji reliabilitas internal menunjukan bahwa HSE Management Standart Indicator tools merupakan alat ukur yang reliabel. Nilai cronbach alpha pada setiap dimensi berkisar antara .81 - .86. dengan nilai Corrected Item-Total Correlation pada setiap butir lebih dari .200. Validitas dilakukan dengan cara melakukan face validity dan content validity. Face validity dilakukan kepada 30 sampel try out sebelum alat ukur digunakan. Content validity didasarkan kepada persetujuan expert. Dalam penelitian ini content validity dilakukan oleh kedua dosen pembimbing dan satu dosen yang ahli di bidang psikologi industri dan organisasi. Hasil uji validitas menunjukan bahwa tidak ada perubahan dari butir alat ukur yang digunakan.

\section{HASIL DAN PEMBAHASAN}

\section{Hasil}

Sebagai cara untuk mengetahui pengaruh dari stres kerja terhadap kualitas hidup dilakukan uji regresi terhadap semua subjek penelitian $(n=227)$, yang hasilnya dapat dilihat pada table 1.5 berikut ini: 
Tabel 5 Hasil Uji Regresi Reaksi Stres Kerja Terhadap Kualitas Hidup

\begin{tabular}{cccccc}
\hline Variabel Prediktor & $\mathrm{F}$ & Beta & $\mathrm{P}$ & $\mathrm{R}$ & R Square \\
\hline Reaksi Stres Kerja & 452.855 & -.817 & $.000(<0.05)$ & 0.817 & 0.668 \\
\hline
\end{tabular}

Nilai F sebesar 452.855 dengan signifikansi (p) sebesar $0.000(\mathrm{p}<0.05)$. Hal ini menunjukan bahwa terdapat pengaruh stres kerja terhadap kualitas hidup. Dari hasil uji regresi didapatkan hasil bahwa nilai $\mathrm{R}$ adalah 0.817 dan koefisien determinasi R2 (R Square) adalah sebesar 0.668. Hal ini menunjukan bahwa stres kerja memberikan sumbangan pengaruh sebesar $66.8 \%$ terhadap kualitas hidup. Nilai Beta negatif, mengindikasikan adanya hubungan terbalik antara stres kerja dengan kualitas hidup. Artinya, semakin tinggi stres kerja, maka akan semakin rendah kualitas hidup, begitu juga sebaliknya, semakin rendah stres kerja maka semakin tinggi kualitas hidup.

Selanjutnya peneliti melakukan uji regresi untuk mengetahui dimensi mana dalam reaksi stres kerja, yang memiliki pengaruh paling tinggi terhadap kualitas hidup. Hasil uji regresi dapat dilihat pada table 1.5 berikut ini:

Tabel 6 Hasil Regresi Dimensi Reaksi Stres Kerja Terhadap Kualitas Hidup

\begin{tabular}{|c|c|c|c|c|}
\hline Variabel 1 & Variabel 2 & $\mathrm{R} 2$ & Beta & Sig \\
\hline & Kualitas Hidup & .680 & & \\
\hline Reaksi Fisik & & & -.420 & .000 \\
\hline Reaksi Psikologis & & & -.408 & .000 \\
\hline Reaksi Perilaku & & & -.140 & .005 \\
\hline
\end{tabular}

Berdasarkan tabel tersebut, dapat dikatakan bahwa secara bersamaan dimensi reaksi fisik, reaksi psikologis, dan reaksi perilaku memberikan pengaruh sebesar 68\% terhadap kualitas hidup. Sisanya, sebesar 32\% dipengaruhi oleh variabel lain yang tidak diteliti. Secara parsial, ketiga dimensi dari stres kerja tersebut memiliki pengaruh secara signifikan dan negatif terhadap kualitas hidup. Artinya, semakin tinggi reaksi stres fisik, stres psikologis dan stres perilaku yang dirasakan oleh subjek, maka akan semakin rendah kualitas hidup pada subjek tersebut. Lebih lanjut diketahui bahwa reaksi stres fisik lebih mempengaruhi kualitas hidup, dibandingkan dengan reaksi stres psikologis dan perilaku.

Selanjutnya peneliti melakukan uji regresi untuk mengetahui dimensi mana dalam reaksi stres kerja, yang memiliki peran paling tinggi terhadap dimensi-dimensi dalam kualitas hidup. Hasil uji statistik menunjukan hasil sebagai berikut.

Tabel 7 Hasil Regresi Dimensi Reaksi Stres Kerja Terhadap Dimensi Kualitas Hidup

\begin{tabular}{lllll}
\hline Variabel 1 & Variabel 2 & R2 & Beta & Sig \\
\hline Reaksi Fisik & Kualitas Hidup Fisik & .708 & -.565 & .000 \\
$\begin{array}{l}\text { Reaksi Psikologis } \\
\text { Reaksi Perilaku }\end{array}$ & & -.095 & .137 \\
& & & -.140 & .023 \\
Reaksi Fisik & Kualitas Hidup Psikologis & .618 & -.224 & .000 \\
Reaksi Psikologis & & & -.622 & .000 \\
Reaksi Perilaku & & & -.033 & .540 \\
& Kualitas Hidup Hubungan & .361 & -.086 & .195 \\
Reaksi Fisik & & & -.507 & .000 \\
Reaksi Psikologis & & & -.064 & .357 \\
Reaksi Perilaku & Kualitas Hidup Lingkungan & .486 & -.380 & .000 \\
Reaksi Fisik & & & -.267 & .000 \\
Reaksi Psikologis & & & -.179 & \\
Reaksi Perilaku & & &
\end{tabular}


Hasil analisis regresi lebih lanjut, antara dimensi dari stres kerja dengan kualitas hidup menunjukan bahwa dimensi fisik stres kerja lebih berperan terhadap kualitas hidup, dibandingkan dengan dimensi psikologis dan perilaku dari stres kerja. Hal ini mengindikasikan bahwa pada karyawan yang sering mengalami gangguan kesehatan akibat dari stres kerja akan lebih cenderung terganggu kualitas hidupnya, dibandingkan karyawan yang mengalami reaksi psikologis dan perilaku dari stres kerja. Meskipun stres fisik lebih berperan terhadap kualitas hidup, hasil uji regresi juga menunjukan bahwa stres psikologis dan perilaku juga berperan signifikan terhadap kualitas hidup karyawan. Sehingga dapat dikatakan bahwa individu yang sehat, secara fisik, psikologis dan perilaku akan lebih cenderung memiliki kualitas hidup yang lebih baik.

Pada dimensi fisik kualitas hidup, diketahui bahwa reaksi stres fisik, lebih berperan dibandingkan dengan reaksi psikologis dan perilaku dari stres. Maka dapat dikatakan keluhan fisik karena stres yang dirasakan secara signifikan dan negatif memberikan kontribusi negatif terhadap kualitas hidup. Oleh sebab itu dapat disimpulkan bahwa subjek yang sering megalami reaksi fisik seperti sakit kepala, flu, badan terasa lesu seringkali merasa tidak puas dengan kemampuan fisik dan kondisi kesehatannya.

Namun perlu juga untuk diketahui, bahwa kualitas hidup fisik juga memiliki peranan terhadap bagaimana individu memandang kondisi fisik dan kesehatannya. Sehingga meskipun individu tersebut dalam keadaan sehat, tetapi karena merasa tidak puas akan kualitas hidup fisik, maka akan ada kecenderungan bahwa dia akan mempersepsikan dirinya sebagai sakit.

Pada dimensi psikologis dari kualitas hidup, diketahui bahwa reaksi stres psikologis lebih berperan dibandingkan dengan reaksi fisik dan perilaku dari stres. Maka dapat dikatakan keluhan psikologis karena stres yang dirasakan secara signifikan dan negatif memberikan dampak terhadap kualitas hidup. Oleh sebab itu dapat disimpulkan bahwa subjek yang sering megalami reaksi psikologis karena stres seperti gelisah, cemas, mood berubah-ubah, seringkali merasa tidak puas dengan kondisi psikologis nya.

Berdasarkan hasil uji regresi antara sumber stres kerja dengan stres kerja dapat dikatakan bahwa secara bersamaan dimensi demands, control, managerial support, peer support, relationships, role dan change secara bersamaan memberikan pengaruh sebesar $52.4 \%$ terhadap stres kerja. Sisanya, sebesar $48.6 \%$ dipengaruhi oleh variabel lain yang tidak diteliti.

Tabel 8 Hasil Regresi Faktor Stres Kerja Terhadap Reaksi Stres Kerja

\begin{tabular}{|c|c|c|c|c|}
\hline Variabel 1 & Variabel 2 & R2 & Beta & Sig \\
\hline & Reaksi Stres Kerja & .524 & & \\
\hline Demands & & & .250 & .000 \\
\hline Control & & & .279 & .000 \\
\hline Man. Support & & & 238 & .000 \\
\hline Peer Support & & & .117 & .053 \\
\hline Relationships & & & .208 & .000 \\
\hline Role & & & -.023 & .644 \\
\hline Change & & & -.050 & .328 \\
\hline
\end{tabular}

\section{Pembahasan}

Pertanyaan dalam penelitian ini adalah bagaimana pengaruh reaksi stres kerja terhadap kualitas hidup pada pekerja level operator cutting di PT.X. Hasil penelitian ini menunjukan reaksi stres kerja mempengaruhi kualitas hidup secara signifikan dan negatif. Artinya semakin tinggi reaksi stres kerja maka akan semakin rendah kualitas hidup pada pekerja. Begitu sebaliknya, semakin rendah reaksi stres kerja maka akan semakin tinggi kualitas hidup pada pekerja. Hasil ini sejalan 
dengan penelitian sebelumnya oleh Zaharia (2016), yang menunjukan bahwa pekerja yang gagal dalam mengelolah stres kerja, cenderung mengalami penurunan kualitas hidup.

Hasil analisis regresi lebih lanjut, antara dimensi dari stres kerja dengan kualitas hidup menunjukan bahwa dimensi fisik stres kerja lebih berpengaruh terhadap kualitas hidup, dibandingkan dengan dimensi psikologis dan perilaku dari reaksi stres kerja. Hal ini mengindikasikan bahwa pada pekerja yang sering mengalami gangguan kesehatan akibat dari reaksi stres kerja akan lebih cenderung terganggu kualitas hidupnya Hasil ini sejalan dengan hasil penelitian yang dilakukan oleh Steinisch, Yusuf, Li, Rahman, Ashraf, Strumpell, Fischer, \& Loerbroks (2013). Di mana karyawan yang mengalami stres kerja, akan cenderung lebih sering mengeluhkan kondisi kesehatan fisik dirinya. Selain itu kondisi kerja yang monoton dan terus menerus di PT.X kemungkinan juga berdampak pada tingginya reaksi fisik dan psikologis yang dirasakan oleh subjek. Hal ini seperti yang diungkapkan oleh hasil penelitian Melamed, Ben-Avi, Luz dan Green (1995), di mana karyawan yang secara objektif maupun subjektif merasa bahwa karyawananya bersifat monoton dan terus menerus, memiliki kecenderungan mengalami tekanan psikologis, seperti munculnya kecemasan, mudah marah dan munculnya gangguan somatik.

Meskipun reaksi stres fisik lebih berpengaruh terhadap kualitas hidup, hasil uji regresi juga menunjukan bahwa reaksi stres psikologis dan perilaku juga berpengaruh signifikan terhadap kualitas hidup pekerja. Sehingga dapat dikatakan bahwa individu yang sehat, secara fisik, psikologis dan perilaku akan lebih cenderung memiliki kualitas hidup yang lebih baik.

\section{KESIMPULAN DAN SARAN}

\section{Kesimpulan}

Diketahui bahwa pada PT.X secara umum, stres kerja terbagi ke dalam lima kategori, di mana sebagian besar subjek berada dalam kategori stres kerja sedang. Lebih lanjut, diketahui bahwa reaksi fisik dari stres kerja, merupakan reaksi yang paling sering dirasakan, dibandingkan dengan reaksi psikologis dan perilaku dari stres kerja. Penelitian juga mengungkapkan bahwa pada pada karyawan level operator cutting di PT.X stres kerja muncul sebagai akibat dari tingginya tuntutan kerja, rendahnya otonomi kerja, rendahnya dukungan managerial serta buruknya iklim hubungan kerja.

Pada subjek dalam kategori stres sangat tinggi dan tinggi, diketahui bahwa kualitas hidup berada dalam kategori rendah. Rerata kualitas hidup sudah mulai terlihat berada dibawah rata-rata ketika subjek berada dalam kategori stres kerja sedang. Hal berbeda ditunjukan pada subjek dengan kategori stres rendah dan sangat rendah. Pada subjek tersebut diketahui bahwa kualitas hidup berada dalam kategori tinggi.

Lebih lanjut, hasil penelitian ini membuktikan bahwa hipotesis yang diajukan dapat diterima, yaitu reaksi stres kerja memiliki peranan secara negatif terhadap kualitas hidup. Penelitian ini menunjukan bahwa terdapat hubungan yang signifikan dengan nilai beta negatif antara stres kerja dengan kualitas hidup pada karyawan level operator cutting di PT.X. Sehingga dapat dikatakan bahwa pada subjek penelitian, semakin tinggi stres kerja maka akan semakin rendah kualitas hidup karyawan. Begitu juga sebaliknya, semakin rendah stres kerja maka akan semakin tinggi kualitas hidup pada karyawan. Oleh sebab itu, stres kerja merupakan aspek yang perlu diperhatikan dalam meningkatkan kualitas hidup karyawan di PT.X. 


\section{Saran}

Penelitian ini tidak terlepas pada keterbatasan. Tidak adanya data kinerja karyawan dalam penelitian ini membuat peneliti tidak dapat membandingkan dampak dari stres kerja dan kualitas hidup terhadap kinerja. Selanjutnya, alat ukur yang digunakan lebih cenderung melihat bagaimana persepsi individu terkait dengan sumber stres kerja, reaksi stres kerja dan kualitas hidup. Sehingga pada penelitian selanjutnya, disarankan untuk menambah data aspek objektif dari stres kerja dan kualitas hidup. Aspek objektif tersebut bisa dalam bentuk, angka kunjungan sakit partisipan, tingkat pendapatan partisipan dan kondisi lingkungan fisik di tempat kerja.

Pada penelitian ini juga ditemukan adanya subjek dengan tingkat reaksi stres kerja yang tinggi, tetapi tetap memiliki kualitas hidup yang baik. Hal tersebut bisa saja diakibatkan karena tingkat resiliensi yang tinggi pada subjek penelitian. Sehingga pada penlitian selanjutnya, variabel resiliensi dapat digunakan sebagai faktor mediasi antara stres dan kualitas hidup.

Saran kepada perusahaan adalah hasil penelitian ini dapat digunakan sebagai bahan untuk membantu meningkatkan kualitas hidup di PT.X. Diketahui bahwa reaksi stres fisik, psikologis dan perilaku memilki pengaruh yang signifikan terhadap kualitas hidup dari karyawan. Sehingga intervensi terhadap ketiga aspek tersebut, dapat membantu karyawan dalam meningkatkan kualitas hidupnya. Pada penelitian ini, peneliti menyusun rancangan intervensi yang dapat digunakan oleh perusahaan. Rancangan intervensi berbasis brief mindfulness diharapkan mampu untuk membantu mengurangi reaksi stres serta merubah cara pandang pekerja terhadap beban kerja. Disamping hal tersebut, hasil penelitian ini juga menunjukan bahwa pada karyawan sumber stres pada dimensi demands, control, managerial support dan relationships memiliki peran signifikan dalam menimbulkan reaksi stres kerja. Berdasarkan hal tersebut, maka perusahaan dapat mempertimbangkan perbaikan yang bisa dilakukan, seperti pelatihan komunikasi efektif untuk meningkatkan kualitas komunikasi antara pihak managemen dengan pekerja.

\section{Ucapan Terima Kasih}

Peneliti mengucapkan terima kasih kepada jajaran manajemen dan seluruh karyawan PT.X yang telah bersedia untuk bekerja sama dan banyak membantu jalannya proses penelitian. Peneliti juga mengucapkan terima kasih kepada Fakultas Psikologi Universitas Tarumanagara yang telah banyak membantu selama penelitian berlangsung.

\section{REFERENSI}

Babu, G., Sudhir, P., Mahapatra, T., Das, A., Rathnaiah, M., Anand, I., \& Detels, R. (2016). Association of quality of life and job stress in occupational workforce of India: Findings from a cross-sectional study on software professionals. Indian Journal of Occupational and Environmental Medicine, 20(2), 109. doi:10.4103/0019-5278.197544

Brenes, G. A. (2007). Anxiety, depression, and quality of life in primary care patients. The Primary Care Companion to The Journal of Clinical Psychiatry, 09(06), 437-443. doi:10.4088/pcc.v09n0606

Cavallini, A., Micieli, G., Bussone, G., Rossi, F., \& Nappi, G. (1995). Headache and quality of life. The Journal of Head and Face Pain, 35(1), 29-35. doi:10.1111/j.15264610.1995.hed3501030.x

Choi, S., Jang, S. H., Lee, K. H., Kim, M. J., Park, S., \& Han, S. H. (2018). Risk factor, job stress and quality of life in workers with lower extremity pain who use video display terminals. Annals of Rehabilitation Medicine, 42(1), 101. doi:10.5535/arm.2018.42.1.101 
International Labour Organization. (2012). Better work Indonesia: Garment industry baseline report. Retrieved from https://betterwork.org/global/wp-content/uploads/ImpactResearch-Indonesia-Baseline-Report-Worker-Perspectives-from-the-Factory-andBeyond.pdf

International Labour Organization. (2016). Workplace stress: A collective challenge. Retrieved from http://www.ilo.org/safework/info/publications/WCMS 466547/lang- en/index.htm

Marques, D. R., Meia-Via, A. M., Silva, C. F., \& Gomes, A. A. (2017). Associations between sleep quality and domains of quality of life in a non-clinical sample: Results from higher education students. Sleep Health, 3(5), 348-356. doi:10.1016/j.sleh.2017.07.004

Melamed, S., Ben-Avi, I., Luz, J., \& Green, M. S. (1995). Objective and subjective work monotony: Effects on job satisfaction, psychological distress, and absenteeism in bluecollar workers. Journal of Applied Psychology, 80(4), 538-538. doi:10.1037/00219010.80 .4 .538

Palmer, S., Cooper, C., \& Thomas, K. (2004). A model of work stress. Counseling at Work.

Perinelli, B., \& Baker, V. A. (2011). Labour conditions and levels of satisfaction. Retrieved August 23, 2018, from https://wageindicator.org/documents/publicationslist/publications2011/Labour-conditions-and-levels-of-satisfaction.pdf

Sarafis, P., Rousaki, E., Tsounis, A., Malliarou, M., Lahana, L., Bamidis, P., Papastavrou, E. (2016). The impact of occupational stress on nurses' caring behaviors and their health related quality of life. BMC Nursing, 15(1). doi:10.1186/s12912-016-0178-y

Sio, S. D., Cedrone, F., Sanità, D., Ricci, P., Corbosiero, P., Traglia, M. D., Stansfeld, S. (2017). Quality of life in workers and stress: Gender differences in exposure to psychosocial risks and perceived well-being. BioMed Research International, 1-6. doi: $10.1155 / 2017 / 7340781$

Steinisch, M., Yusuf, R., Li, J., Rahman, O., Ashraf, H. M., Strümpell, C., \& Loerbroks, A. (2013). Work stress: Its components and its association with self-reported health outcomes in a garment factory in Bangladesh: Findings from a cross-sectional study. Health \& Place, 24, 123-130. doi:10.1016/j.healthplace.2013.09.004

Sodexo. (2015). How leaders value quality of life in their organization. Retrieved August 18, 2018, from http://www.qualityoflifeobserver.com/content/quality-of-life-survey

Susniene, D., \& Jurkauskas, A. (2009). The concepts of quality of life and happiness: Correlation and differences. Engineering Economics, 3, 58-66.

World Health Organization. (2007). Raising awareness of stress at work in developing countries. Retrieved August 18, 2018, from https://www.who.int/occupational_health/publications/raisingawarenessofstress.pdf?ua=1

WHOQOL-Group. (1998). Development of the world health organization WHOQOL-BREF quality of life assessment. Psychological Medicine, 28(3), 551-558. doi: $10.1017 / \mathrm{s} 0033291798006667$

Zaharia, A. (2017). Psychosocial aspects of the relation between the occupatiopnal stress and the quality of life. Psiworld 2016 Proceedings. doi:10.15303/rjeap.2017.si1.a43 